\title{
Multilevel Predictors of Math Classroom Climate: A Comparison Study of Student and Teacher Perceptions

\author{
Ming-Te Wang
} \\ University of Pittsburgh \\ Jacquelynne S. Eccles \\ University of Michigan
}

Math classroom climate has been linked with math achievement and is often a potential target of school reform initiatives. This study examined the extent to which student and teacher perceptions differed as a function of individual, classroom, and school characteristics. Data came from 2,950 seventh graders in 134 math classes within 25 middle schools. Multilevel analyses indicated that classroom-level characteristics exerted greater influence upon the classroom perceptions of both students and teachers than school-level characteristics. Furthermore, only small correlations were found between student and teacher reports on promotion of collaboration and provision of autonomy support. Finally, the effect of within-class ability grouping on classroom climate varied by class size and heterogeneity among classmates' math ability.

Improving student mathematics performance has been, and continues to be, an important educational goal. Without math proficiency, students will struggle to develop the critical thinking and problem-solving skills that are necessary for full participation in society and success in life. Since the No Child Left Behind Act (NCLB) was adopted in 2002, promotion of greater understanding among schools and educators of the characteristics that lead to effective math classrooms has become a key goal in school reform initiatives (Foundation for Success, 2008). To study those characteristics of math classrooms that create optimal learning and motivational contexts, one needs both strong theory and measures. Over the last 40 years, great headway has been made in generating strong theory. However, what individual and contextual characteristics lead to supportive math classroom climate and how best to measure classroom climate are still open questions.

Research implementing stage-environment fit and self-determination theoretical frameworks has focused on what structural characteristics (e.g., class size), and which processes within the classroom environment (e.g., teacher-student relationship), shape a positive classroom climate. These theoretical frameworks have emphasized the motivational role of perceptions, beliefs, and interpretations held by the individual (Deci \& Ryan, 2000; Wigfield, Eccles, Davis-Kean, Roeser, \& Scheifele, 2006). According

Requests for reprints should be sent to Ming-Te Wang, School of Education, Learning Research and Development Center, Department of Psychology, University of Pittsburgh, 230 South Bouquet Street, Pittsburgh, PA 15260. E-mail: mtwang@pitt.edu to these theoretical frameworks, classroom climate is optimized when individuals perceive that the learning context fulfills their needs for competence, autonomy, and relatedness (Deci \& Ryan, 2000) and supports the students' confidence in their ability to master the material being taught and the value the students attach to learning the material (Eccles et al., 1993). Both students' need for competence and confidence in their ability to master the material is fostered when they experience their classroom settings as optimal in structure, perceive that their teachers have confidence in their abilities, and know what they need to do to be successful (Skinner \& Belmont, 1993). Both the students' need for autonomy and the value they attach to the material being taught is promoted when they experience freedom in determining their behavior and when they believe what they are being taught is meaningful to them (Wigfield et al., 2006). The need for relatedness is supported when teachers create a socially and emotionally supportive environment (Connell \& Wellborn, 1991). These theoretical and empirical works enable us to conceptualize math classroom climate as a function of the dynamic interactions between individuals and their classroom environments at different ecological levels (Bronfenbrenner, 1979).

Despite increased interest in research and practice aimed at improving classroom climate in math specifically, there remain two major shortcomings in the existing literature on classroom climate. First,

(C) 2014 The Authors

Journal of Research on Adolescence (C) 2014 Society for Research on Adolescence DOI: 10.1111/jora.12153 
although the classroom climate literature has identified several critical characteristics of an effective math classroom and linked these to math achievement, we know little about the extent to which individual demographic characteristics (e.g., gender and ethnicity) and school or classroom structure (e.g., teacher turnover and class size) independently or jointly influence student and teacher perceptions of classroom climate, even though ample evidence suggests that individual characteristics influence perceptions of social phenomena (Mitchell, Bradshaw, \& Leaf, 2010). If we are to understand the predictive role of classroom characteristics on student learning, motivation, and achievement, we need to understand the role that personal and structural characteristics play in the perceptions of these contexts. Second, most of the data collected on classroom climate rely primarily on student-report surveys. Classroom processes are relational and dynamic, and they involve ongoing interaction and communication between teachers and students (Pianta \& Hamre, 2009). Teacher perceptions of classroom climate may differ from those of their students. Collecting information from teachers can provide an alternative and important perspective on classroom climate (Feldlaufer, Midgley, \& Eccles, 1988; Mitchell et al., 2010). The use of multi-informants (i.e., teacher and student) to study different aspects of classroom climate will help us to examine to what extent student perceptions and teacher perceptions of math classroom climate converge or diverge.

Drawing on stage-environment fit and self-determination theoretical frameworks, we use a multilevel perspective to identify individual, classroom or teacher, and school characteristics that influence student and teacher perceptions of math classroom climate and how these characteristics may interact with each other. In addition, we compare the predictive relation of two types of classroom climate measures: teacher and student reports. Specifically, we investigate the correspondence between student and teacher perceptions of the math classroom characteristics proposed as critical in stage-environment fit and self-determination theories of achievement motivation, as well as the extent to which student and teacher perceptions differ as a function of individual, classroom or teacher, and school characteristics.

\section{Assessing Math Classroom Climate}

It is well documented that classroom climate influences students' social-emotional and academic outcomes (Pianta \& Hamre, 2009; Wang, 2009).
Positive classroom climate is associated with greater mastery motivation, school satisfaction, academic performance, and less disruptive behavior (Baker, 1999; Barth, Dunlap, Dane, Lochman, \& Wells, 2004; Ryan \& Grolnick, 1986). Recent research on academic motivation and engagement has identified four aspects of classroom climate that are central to students' math achievement: (1) authentic instruction, (2) collaboration promotion, (3) autonomy support, and (4) teacher social support (Cleary \& Chen, 2009; Patrick, Kaplan, \& Ryan, 2011; Wigfield et al., 2006). These classroom characteristics are particularly important for adolescents during the middle school years as they support early adolescent developmental needs for competency, autonomy, and relatedness in the math classroom (Eccles, Lord, \& Midgley, 1991).

Authentic instruction includes tasks that emphasize real-life importance and promote connections to the world beyond the classroom (Newman \& Wehlage, 1993). Meaningful and authentic instruction provides opportunities for students to connect personal goals and interests to classroom experiences, increasing their feelings of competence and autonomy and supporting the subjective task value they attach to the course material (Gentry \& Owen, 2004; Wang, 2012). Instruction that facilitates interaction and cooperation can increase students' interest and foster competence and commitment to the class (Newman \& Wehlage, 1993). Autonomy support can promote academic achievement through the sense of personal satisfaction and responsibility that students experience when they exert influence on their learning environment (Reeve, Jang, Carrell, Jeon, \& Barch, 2004; Wang, 2009; Wang \& Holcombe, 2010). Furthermore, teachers who like and respect their students and who show an interest in what their students have to say provide the kind of socio-emotional support that students need to approach, engage in, and persist on academic learning tasks (Roeser \& Eccles, 1998; Wang, 2012; Wigfield et al., 2006). However, it is not yet clear what individual or structural characteristics promote or undermine positive perceptions of classroom climate.

According to stage-environment fit theory (Eccles et al., 1993), student and teacher perceptions of classroom climate result from the interaction of the individual with the context and are responsive to variations in school and classroom characteristics. Recent school climate studies have employed three-level modeling (individuals, classrooms, and schools) and have found that structural characteristics at each of these levels account for a 
substantial proportion of the variability in perceived school climate (Koth, Bradshaw, \& Leaf, 2008; Mitchell et al., 2010). These findings imply that student and teacher perceptions of classroom climate may also differ depending on which student, classroom, teacher, and school characteristics are investigated. Thus, a multilevel approach is appropriate for identifying both the individual and contextual characteristics that influence student and teacher perceptions of classroom climate. Below, we review potential factors at each level that may influence the four aspects of classroom climate: authentic instruction, collaboration promotion, autonomy support, and teacher social support.

\section{Individual-level Factors}

Gender, ethnicity, socioeconomic status (SES), and student achievement levels each differentially predict students' perceptions of math classroom climate. Ethnic minority, low SES, and low-performing students tend to perceive the classroom environment less favorably (Battistich, Solomon, Kim, Watson, \& Schaps, 1995; Griffith, 2000; Jussim \& Harber, 2005; Kuperminc, Leadbeater, \& Blatt, 2001). Ethnic minority students and students from lower social class family backgrounds report less social support and less promotion of class collaboration and autonomy support by teachers (Wang \& Eccles, 2012). Furthermore, students at risk for academic failure or discipline problems are less likely to feel supported by teachers and therefore may perceive the classroom environment more negatively (Flores \& Kaylor, 2007).

Boys and girls may perceive the math classroom differently due to the differential treatment experienced in class (Wang \& Degol, 2013), as well as different perceptual biases. Indeed, the American Association of University Women Annual Report (1992) concluded that boys receive more attention and esteem-building encouragement from teachers; that classroom activities were generally more maleoriented; and that teacher-student interactions in math class were particularly favorable toward boys. Recent research also indicates that girls report lower teacher expectation and less classroom teaching time spent on learning and activity that are perceived as relevant to the world outside of the classroom (Gentry \& Owen, 2004; Green, 2002; Jussim \& Harber, 2005). Even high-achieving girls are seen by teachers as being less logical, less independent in math, and liking math less than their equally achieving boy counterparts (Tiedemann,
2002). In addition, girls tend to respond more positively to math instruction if it is taught in a cooperative or individualized manner rather than a competitive manner (Wang, 2012). If particular teaching practices and instructional foci are more prevalent in math class, then one would expect to see gender differences in the perceptions of classroom climate.

\section{Classroom- or Teacher-level Factors}

Class composition and teacher characteristics may influence student and teacher experiences and perceptions of class climate (Eccles \& Roeser, 2011; Koth et al., 2008). Small class size enhances the likelihood of positive interaction between students and teachers and increases the opportunity for individualized instruction (Deutsch, 2003; Haughey, Snart, \& Costa, 2001). Thus, it is possible that class size influences student and teacher experiences and perceptions of social and academic support (Darling-Hammond, Ancess, \& Ort, 2002; Leithwood \& Jantzi, 2009). Likewise, grouping students based on their performance ability within classrooms may have a proximal influence on the classroom environment and, in turn, influence student and teacher perceptions of the classroom climate (Epstein, Atkins, Cullinan, Kutash, \& Weaver, 2008). Although many researchers believe withinclass ability grouping is a workable approach to instructing students with different math skill levels (Lou et al., 1996; Mulkey, Catsambia, Steelman, \& Crain, 2005), other evidence reveals inconsistent effects of ability grouping on math achievement, particularly for students with lower math ability (Fuligni, Eccles, \& Barber, 1995; Gamoran \& Mare, 1989). Such results suggest that ability grouping within class may raise competence beliefs in high math achievement students while depressing selfesteem in students with lower math achievement. Some studies indicate that the effect of within-class ability grouping depends on the class size, with ability grouping in larger classes having more of a positive effect on student math achievement than in smaller classes (e.g., Lou et al., 1996). Thus, it is plausible that within-class ability grouping may influence student and teacher perceptions of classroom climate differentially depending on class size as well.

Heterogeneity in classroom ability may also influence both student and teacher perceptions of the classroom through the way teachers organize and teach the class (Eccles et al., 1993; Wang \& Degol, 2013). For example, if the teacher adopts a 
"one size fits all" approach to class organization, academic curriculum, and instruction, the fit between instruction and students' varying subjectmatter ability will differ. Material is bound to be too difficult for some of the students and too easy for others, leading to differential experiences and perceptions of the intellectual demands and of one's own sense of competence in math class. Additionally, whole group instruction that has everyone working on the same material and taking the same tests encourages social comparison, further contributing, indirectly, to the potential for differential experiences and perceptions of the math classroom among students. In contrast, ability grouping or individualized instruction could prevent social comparison among students by decreasing the amount of variation in math ability and performance that each student experiences in the classroom. Taken together, the effect of within-class ability grouping on classroom climate perceptions may vary by heterogeneity of classroom ability.

On the teacher level, male teachers and ethnic minority teachers tend to perceive classroom environments less favorably (Bevans, Bradshaw, Miech, \& Leaf, 2007). Teacher qualification — such as certification, majoring in the subject matter one teaches, and years of teaching experience-predicts both student and teacher perceptions of teaching effectiveness and, consequently, student achievement (Akiba, LeTendre, \& Scribner, 2007; Koedel, 2009). It is likely that less qualified and less experienced teachers perceive the school environment as being less supportive and feel less effective at their job than their more experienced colleagues (Hoy \& Woolfolk, 1993; Koth et al., 2008; Powers, 2003). Junior teachers have been shown to struggle with the implementation of effective teaching strategies (e.g., promoting collaboration among students) and effectively influencing the motivation of students in class (Rockoff, 2004). Similarly, students may perceive such teachers as less effective than their more experienced and credentialed counterparts.

\section{School-level Factors}

The influence of school structural characteristics on perceptions of classroom climate has received little attention. School-level factors, including school size (Archibald, 2006; McNeely, Nonnemaker, \& Blum, 2002; Welsh, 2000), faculty turnover rate (Birnbaum et al., 2003), student-teacher ratio (Griffith, 1995), and student mobility (Griffith, 2000), have been linked to perceptions of school climate, but it is plausible that such school characteristics also influ- ence experiences at the classroom level. Students at larger schools and in schools with higher teacher turnover are more likely to experience fewer interactions with teachers and fewer opportunities for independence and autonomy (Baker et al., 2001; Lee, Smith, \& Croninger, 1997). Moreover, the relationship between aggregated indicators of student characteristics (e.g., SES and ethnicity) and perceptions of school climate is well established (Rosenholtz, 1989). Students in high-poverty schools (measured by the percentage of students qualifying for the federal school lunch program) and schools with high percentages of minority students generally have more academic difficulties and less pleasant school experiences (Battistich et al., 1995; Rutter \& Maughan, 2002). In this study, we investigate whether factors at the school level that affect perceptions of school climate have a similar impact on perceptions of the classroom climate.

\section{The Current Study}

In the present study, we aim to examine (1) what factors operating at different ecological levels (i.e., individual, classroom or teacher, and school) predict student and teacher perceptions of four distinct aspects of math classroom climate (i.e., authentic instruction, collaboration promotion, autonomy support, and teacher social support) and (2) to what extent student-report and teacher-report data of math classroom climate show concordance. In particular, we use a multilevel approach to compare parallel student and teacher models and investigate the convergence and divergence between teacher and student reports of classroom climate, while controlling for the students' and teachers' prior perceptions of classroom climate and math achievement. Based on previous studies, we hypothesize that classroom-level factors will be more predictive of students' and teachers' perceptions of the classroom climate than school-level factors because classroom or teacher-level factors are likely to be a more salient feature of math classrooms than school-level factors. In addition, we expect to find positive effects of within-class ability grouping on student and teacher perceptions of classroom climate when the class size is large and the heterogeneity of ability levels is large. Overall, we extend the classroom climate literature (1) using a largescale and longitudinal sample of middle school students and their math teachers, (2) including multi-level predictors in explaining math classroom climate, and (3) incorporating perspectives from students and teachers and examining the predictive 
relations between student and teacher reports of classroom climate.

\section{METHOD}

\section{Sample}

The sample consisted of U.S. middle school students and their math teachers from the Michigan Study of Adolescent Life Transitions-an ongoing study into the links between school and family experience and the ontogeny of adolescents' academic motivation and behavior. Data for this study were collected from 2,950 seventh-grade students in 134 seventh-grade math classes within 25 suburban public schools located in working- and middle-class communities in Michigan. In seventh grade, students' mean age was 12.4 years $(S D=0.29)$, $90 \%$ were White, $52 \%$ were female, and the majority of the families $(96 \%)$ had two parents living in the home. Forty percent of mothers and $42 \%$ of fathers had earned a degree from a 4 -year college. Families' annual household income ranged between under $\$ 10,000$ to over $\$ 100,000$ (median $=\$ 55,000-\$ 65,000, S D=\$ 9,545$ ). Of the 132 seventh-grade math teachers included in the study, 59\% were female, $85 \%$ were White, $30 \%$ had been teaching at the school for five or fewer years, and 35\% had a master's degree or higher. Thirtyfour percent of the math teachers used within-class ability grouping. The seventh-grade math class size ranged from 12 to 42 students $(M=27.64)$. The number of seventh-grade math classrooms per school ranged from 10 to 20 classrooms $(M=14.50)$. Total school enrollment ranged from 720 to 1,432 students $(M=974)$. The percentage of turnover of math faculty ranged from $0 \%$ to $35 \%$, and student mobility (the phenomenon of students changing schools for reasons other than grade promotion) ranged from $7 \%$ to $11 \%$. The percentage of students receiving free or reduced-price meals ranged from $5 \%$ to $67 \%$.

\section{Procedure}

Students and teachers were recruited through schools. Letters describing the study and permission slips were given to families by teachers. Ninety-nine percent of the math teachers and $90 \%$ of the families across the schools agreed to participate. Student and teacher data were collected at school during the school year. In the seventh grade, field staff administered surveys to the student participants during the period in which they normally received mathematics instruction. The student surveys were anonymous but were linked to the student's math teacher. Research staff members were available to answer students' questions. During the same testing periods, math teachers completed a classroom climate survey. Data were also collected from the parents, but the only parent information used in this study was family socioeconomic status (parent education and family income).

\section{Measures}

Classroom climate. The classroom climate survey was administered in the fall and spring of seventh grade. It was used to assess math classroom climate and contains multiple items that can be combined to form various subscales. Items for each subscale were adapted from existing well-established scales (Feldlaufer et al., 1988; Mac Iver, 1988; Marks, 2000; Meyer \& Turner, 2002; Midgley, Feldlaufer, \& Eccles, 1989; Midgely et al., 1998) and were specifically worded to be relevant to math class. A student measure of classroom climate was created to be as conceptually similar to a corresponding teacher-reported measure as possible. Both student and teacher versions had seventeen item questions. Previous research has indicated that the measure of student and teacher perceptions of classroom climate has strong psychometric properties, including internal consistency and construct validity (Eccles, Lord, Roeser, Barber, \& Jozefowicz, 1997; Feldlaufer et al., 1988; Mac Iver, 1988; Midgley et al., 1989).

The classroom climate survey was used to tap into students' and teachers' perceptions of the four aspects of math classroom environment: (1) authentic instruction, (2) collaboration promotion, (3) autonomy support, and (4) teacher social support. Below, we provide example items from student- and teacher-reported measures. The Authentic Instruction subscale included three items and assessed the extent to which the curriculum and design of instruction were meaningful, relevant, and related to students' personal goals and interests (e.g., "We discuss math problems and issues that are meaningful to us" and "I provide opportunities to discuss math problems and issues that are meaningful to students"). The Collaboration Promotion subscale consisted of five items and assessed the extent to which the teacher promoted collaboration and interaction (e.g., "We get to work with each other in small groups 
when we do math" and "Students are encouraged to work with each other in small groups when they do math"). The Autonomy Support subscale consisted of five items and assessed student opportunities to make decisions related to academic tasks during class (e.g., "The teacher asks us what we want to learn about in math" and "I ask students what they want to learn about in math"). The Teacher Social Support subscale consisted of four items and assessed the level of care and support from teachers (e.g., "The teacher cares how we feel" and "I care how my students feel"). All items were rated on a 5-point scale, ranging from 1 (not very often) to 5 (very often). The subscale scores were calculated by averaging the items. Means, standard deviation, and internal consistency for each subscale are presented in Table 1.

Student-level variables. We included a vector of variables related to student demographic characteristics and math achievement including gender, ethnicity, socioeconomic status (SES), and standardized math scores from the Michigan Educational Assessment Test (MEAP) in the fall of seventh grade. We standardized and added the parent education and annual family income to create a composite measure of SES. In addition, student reports of problem or disruptive behaviors were obtained in seventh grade using the Problem Behavior Scale (Elliott, Huizinga, \& Menard, 1989). This scale is the average of six items that measure the extent to which the students engage in misconduct (e.g., during the past 6 months, how often have you skipped class?). Each question on this measure was rated along a 5-point scale, ranging from 1 (almost never) to 5 (almost always).

Classroom or teacher-level variables. Teachers completed a brief questionnaire including questions regarding their gender, ethnicity, education (bachelor $=0$ and master level and above $=1$ ), number of years teaching at this school, class size, and use of within-class ability grouping. We also used the mean and the standard deviation of students' math scores on the MEAP. The mean provides an estimate of students' average math ability, and the standard deviation provides an indicator of class heterogeneity in math achievement.

School-level variables. School enrollment, faculty turnover (percentage of math teachers new to the school that year), student mobility (number of students moving in plus the number moving out, divided by total enrollment), student-teacher ratio (calculated by dividing the number of students by the number of math teachers at the school), and school SES (percentage of students receiving free or reduced-price meals) were obtained from the school records.

\section{Analytic strategies}

To address our research questions, we fit a series of multilevel models in the HLM 6.02 software (Raudenbush, Bryk, \& Congdon, 2005). A multilevel modeling technique was selected because of the nested nature of our data and research ques-

TABLE 1

The Unconditional Multilevel Models for Student- and Teacher-Reported Classroom Climate in Math

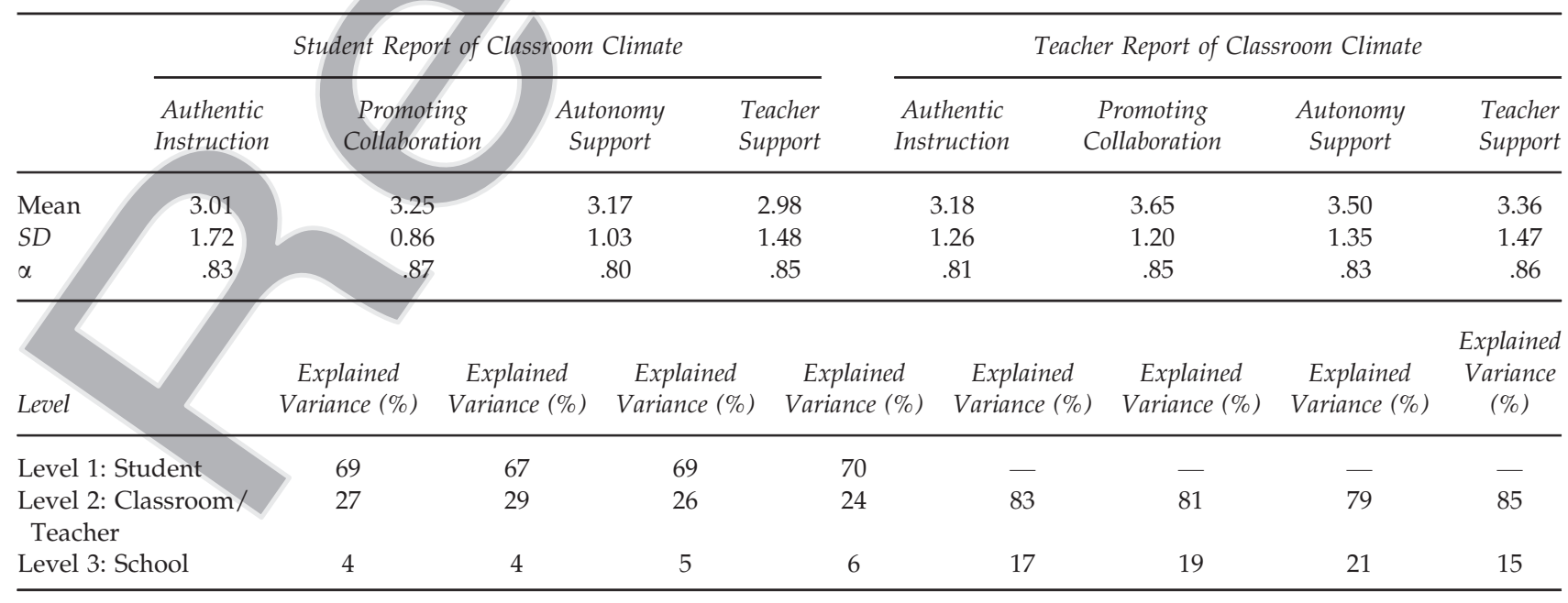


tions (Singer \& Willett, 2003). First, we calculated the amount of variance for each level by fitting unconditional hierarchical linear models without any covariates separately for student report and teacher report of each classroom climate outcome, thereby measuring the amount of variance in classroom climate that occurs across the two or three levels. Second, we fit a series of models to examine the influences of factors at different levels on classroom climate. For teachers, we fit a two-level model to predict teacher perceptions of classroom climate for each outcome. Specifically, we included classroom-level factors at Level 1 and the school-level factors at Level 2. We also averaged the student-level factors (e.g., student gender, achievement, problem behavior) and included them as classroom-level predictors. For students, we fit a three-level model to predict student perceptions of classroom climate for each outcome. Specifically, we included student-level variables at Level 1, classroom-level variables at Level 2, and school-level variables at Level 3. In addition, we included teacher reports of classroom climate as classroom-level variables to examine the extent to which teacher perception of classroom climate predicted student perceptions of classroom climate. Continuous covariates were centered using grand mean centering, while dichotomous covariates were retained as uncentered. Third, based on the theoretical and empirical evidence, we explored possible within-level interactions separately for each level and between-level interactions by testing a series of OLS regressions. For the student perception model, we found two within-level interaction effects (Class size $\times$ Ability grouping and Class heterogeneity in math score $\times$ Ability grouping). For the teacher perception model, we found one interaction effect (Class size $\times$ Ability grouping). No significant between-level interactions were found. Thus, we entered these interactions in the multilevel models to examine the association of the interaction within the multilevel framework. Finally, at each step of the model building, we checked each parameter individually to examine the significance of the residual variance. Any covariates with nonsignificant variances were fixed (Raudenbush \& Bryk, 2002). We used maximum likelihood estimation with robust standard errors to estimate the parameters and examined the model fit on the basis of the Akaike information criterion (Akaike, 1974), the Bayesian information criterion, and the likelihood ratio test (Raudenbush \& Bryk, 2002).

\section{RESULTS}

\section{Unconditional Models}

The partitioning of variance for both student report (SR) and teacher report (TR) of classroom climate outcomes is displayed in Table 1. For SR, the majority of the variance was explained by betweenstudent variation $(67 \%-70 \%)$. The clustering of students within classrooms accounted for $24 \%-29 \%$ of the variance in the four aspects of classroom climate, and clustering of students within schools accounted for an additional $4 \%-6 \%$ of the total variance. For TR, between-classroom variation accounted for the majority of the variance in teacher perceptions of classroom climate (79\%-85\%) and clustering of teachers within schools accounted for additional $15 \%-21 \%$ of the variance.

\section{Multilevel Models}

In Tables 2-5, we present the model-fitting results for student and teacher perceptions of classroom climate, respectively. Model 1 describes the main effects of the individual-, classroom-, and schoollevel covariates. Model 2 depicts the within-level interaction effects. Model 3 describes whether teacher perception of classroom climate predicted student perceptions of classroom climate.

\section{Student Models}

As shown in Tables 2 and 3, at the individual level girls perceived lower levels of authentic instruction but higher levels of collaboration promotion, autonomy support, and teacher social support than boys. Students with higher SES reported higher levels of authentic instruction, autonomy support, and teacher social support than those with lower SES. Moreover, students who had more problem behaviors reported lower levels of authentic instruction, collaboration promotion, autonomy support, and teacher social support than students who had fewer problem behaviors. Finally, students with higher math achievement perceived all four aspects of classroom climate more favorably than students with lower math achievement.

At the classroom level, students with more experienced teachers perceived more authentic instruction and more collaboration and autonomy than students with less experienced teachers. Students perceived more authentic instruction in classes with smaller class size and higher average math scores. There were no significant effects for teacher 
TABLE 2

Multilevel Results for School, Classroom, and Individual-Level Effects on Student-Reported Authentic Instruction and Collaboration Promotion

\begin{tabular}{|c|c|c|c|c|c|c|}
\hline Variables & $\begin{array}{c}\text { Model 1a: } \\
\text { SR Authentic } \\
\text { Instruction } \\
\beta(S E)\end{array}$ & $\begin{array}{c}\text { Model 2a: } \\
\text { SR Authentic } \\
\text { Instruction } \\
\beta(S E)\end{array}$ & $\begin{array}{c}\text { Model 3a: } \\
\text { SR Authentic } \\
\text { Instruction } \\
\beta(S E)\end{array}$ & $\begin{array}{c}\text { Model 1b: } \\
\text { SR Promoting } \\
\text { Collaboration } \\
\beta(S E)\end{array}$ & $\begin{array}{l}\text { Model } 2 b \text { : } \\
\text { SR Promoting } \\
\text { Collaboration } \\
\beta(S E)\end{array}$ & $\begin{array}{c}\text { Model 3b: } \\
\text { SR Promoting } \\
\text { Collaboration } \\
\beta(S E)\end{array}$ \\
\hline \multicolumn{7}{|l|}{ Student level } \\
\hline Student gender & $.20^{* * *}(.04)$ & $.22^{* * *}(.05)$ & $.22^{* * *}(.05)$ & $-.08^{*}(.03)$ & $.06^{*}(.03)$ & $-.07^{*}(.03)$ \\
\hline Student race/ethnicity & $-.08(.05)$ & $-.06(.04)$ & $-.06(.04)$ & $.09(.09)$ & & $.05(.06)$ \\
\hline SES & $.12^{* *}(.03)$ & $.13^{* *}(.04)$ & $.13^{* *}(.04)$ & $.04(.05)$ & $.02(.06)$ & $.01(.05)$ \\
\hline Problem behavior & $-.30^{* * *}(.06)$ & $-.28^{* * *}(.07)$ & $-.28^{* * *}(.07)$ & $-.20^{* * *}(.0$ & $-.17^{* * *}(.05)$ & $-.19^{* * *}(.06)$ \\
\hline Math score & $.45^{* * *}(.05)$ & $.42^{* * *}(.06)$ & $.42^{* * *}(.06)$ & & $-.15^{* * *}(.03)$ & $-.16^{* * *}(.03)$ \\
\hline $\begin{array}{l}\text { Prior SR authentic } \\
\text { instruction }\end{array}$ & - & $.36^{* * *}(.09)$ & $.35^{* * *}(.08)$ & & & - \\
\hline $\begin{array}{l}\text { Prior SR collaboration } \\
\text { promotion }\end{array}$ & - & 一 & - & & & $.40^{* * *}(.09)$ \\
\hline \multicolumn{7}{|l|}{ Classroom/teacher level } \\
\hline Teacher gender & $.08(.05)$ & $.06(.05)$ & $.06(.05)$ & $.05(.03)$ & $.02(.02)$ & $.02(.02)$ \\
\hline Teacher race/ethnicity & $.10(.07)$ & $.08(.07)$ & $.08(.07)$ & $-.04(.06)$ & $-.02(.04)$ & $-.03(.04)$ \\
\hline Teaching years & $.14^{* *}(.04)$ & $.14^{* *}(.04)$ & $.13^{* *}(.04)$ & $.09 *(.04)$ & $.07^{*}(.03)$ & $.08^{*}(.04)$ \\
\hline Teacher education & $.08(.06)$ & $.05(.06)$ & $.05(.06)$ & $.04(.06)$ & $.05(.08)$ & $.06(.06)$ \\
\hline Class size & $-.15^{* *}(.05)$ & $-.08^{*}(.04)$ & $-.08^{*}(.04)$ & $-.12^{* *}(.03)$ & $-.08^{*}(.03)$ & $-.09 *(.04)$ \\
\hline Average math score & $.21^{* * *}(.05)$ & $.19^{* * *}(.05)$ & $.19^{* * *}(.05)$ & $.20^{* * *}(.05)$ & $.18^{* * *}(.04)$ & $.20^{* * *}(.05)$ \\
\hline Heterogeneity in math score & $.13(.07)$ & $.08(.07)$ & $.09(.06)$ & $.14^{*}(.05)$ & $.10^{*}(.04)$ & $.11 *(.04)$ \\
\hline Ability grouping & $\sim .12(.06)$ & $.06(.08)$ & $.06(.08)$ & $.12 *(.05)$ & $.06(.06)$ & $.05(.06)$ \\
\hline $\begin{array}{l}\text { Class size } \times \text { Ability } \\
\text { grouping }\end{array}$ & - & $.07(.08)$ & $.07(.08)$ & - & $.15^{* * *}(.05)$ & $.17^{* *}(.05)$ \\
\hline $\begin{array}{l}\text { Heterogeneity in math } \\
\text { score } \times \text { Ability grouping }\end{array}$ & - & & $(.06)$ & - & $.18^{* *}(.06)$ & $.20^{* * *}(.05)$ \\
\hline TR authentic instruction & - & & & - & - & - \\
\hline $\begin{array}{l}\text { TR collaboration } \\
\text { promotion }\end{array}$ & - & & 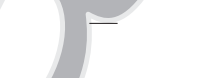 & - & - & $.26^{* * *}(.06)$ \\
\hline \multicolumn{7}{|l|}{ School level } \\
\hline School size & $.04(.09)$ & $.05(.10)$ & $.05(.10)$ & $-.04(.09)$ & $-.02(.07)$ & $-.01(.07)$ \\
\hline Faculty turnover & $-.08(.06)$ & $-.06(.07)$ & $-.06(.07)$ & $-.07(.06)$ & $-.04(.04)$ & $-.02(.02)$ \\
\hline Student mobility & $.06(.05)$ & $.05(.07)$ & $.05(.07)$ & $.04(.05)$ & $.05(.06)$ & $.03(.05)$ \\
\hline Student-teacher ratio & $-.12^{* *}(.03$ & $-.10^{* *}(.03)$ & $-.10^{* *}(.03)$ & $-.07^{*}(.03)$ & $-.06^{*}(.03)$ & $-.07^{*}(.03)$ \\
\hline FARMS & $-.04(.09)$ & $-.02(.08)$ & $-.02(.08)$ & $.06(.08)$ & $.04(.09)$ & $.02(.08)$ \\
\hline $\mathrm{AIC}$ & 1553.8 & 1547.3 & 1509.3 & 1643.4 & 1637.6 & 1600.6 \\
\hline BIC & 1604.6 & 1595.4 & 1578.2 & 1689.2 & 1681.7 & 1652.5 \\
\hline
\end{tabular}

Note. Student gender, $0=$ female, $1=$ male; student race/ethnicity, $0=$ White, $1=$ non-White; SES = socioeconomic status; SR = student report; teacher gender, $0=$ female, $1=$ male; teacher ethnicity, $0=$ White, $1=$ non-White; teaching years $=$ number of years teacher has taught at this school; teacher education, $0=$ bachelor's degree, $1=$ master's level or higher; class size $=$ number of students in the class; average math score = mean math score in the classroom; TR = teacher report; FARMS = free or reduced-priced meals; $\mathrm{AIC}=$ Akaike information criterion; $\mathrm{BIC}=$ Bayesian information criterion.

$* p<.05 ; * * p<.01 ; * * p<.001$.

gender, ethnicity, or teacher education. Moreover, we found two within-level interactions (Class size $\times$ Within-classroom ability grouping and Class heterogeneity in math achievement $\times$ Within-classroom ability grouping). The interaction of Class size $\times$ Within-classroom ability grouping shows the differences in classroom climate in classrooms using and not using within-classroom ability grouping as class size increases. The positive effect of within-classroom ability grouping on classroom climate increases as the class size rises. In smaller classes $(n<27)$, differences in the perceived levels of collaboration promotion $(\beta=.05, n s)$ and autonomy support $(\beta=.03, n s)$ were not statistically significant between classrooms with and without within-classroom ability grouping. In contrast, in larger classes $(n>27)$, students in the classrooms with within-classroom ability grouping perceived greater levels of collaboration promotion $(\beta=.22$, $p<.001)$ and autonomy support $(\beta=.18, p<.001)$ than students in classrooms with no ability grouping. 
TABLE 3

Multilevel Results for School, Classroom, and Individual-Level Effects on Student-Reported Autonomy Support and Teacher Support

\begin{tabular}{|c|c|c|c|c|c|c|}
\hline Variables & $\begin{array}{c}\text { Model 1c: } \\
\text { SR Autonomy } \\
\text { Support } \\
\beta(S E)\end{array}$ & $\begin{array}{c}\text { Model 2c: } \\
\text { SR Autonomy } \\
\text { Support } \\
\beta(S E)\end{array}$ & $\begin{array}{c}\text { Model 3c: } \\
\text { SR Autonomy } \\
\text { Support } \\
\beta(S E)\end{array}$ & $\begin{array}{l}\text { Model 1d: } \\
\text { SR Teacher } \\
\text { Support } \\
\beta(S E)\end{array}$ & $\begin{array}{c}\text { Model 2d: } \\
\text { SR Teacher } \\
\text { Social Support } \\
\beta(S E)\end{array}$ & $\begin{array}{c}\text { Model 3d: } \\
\text { SR Teacher } \\
\text { Social Support } \\
\beta(S E)\end{array}$ \\
\hline \multicolumn{7}{|l|}{ Student level } \\
\hline Student gender & $-.16^{*}(.07)$ & $-.12 *(.05)$ & $-.13^{*}(.05)$ & $-.10^{*}(.04)$ & $-.07^{*}(.03)$ & $-.08^{*}(.04)$ \\
\hline Student race/ethnicity & $-.04(.09)$ & $-.01(.08)$ & $-.02(.09)$ & $.01(.09)$ & & $.00(.08)$ \\
\hline SES & $.14^{* *}(.04)$ & $.11^{* *}(.03)$ & $.12^{* *}(.04)$ & $.16^{* *}(.06)$ & $.14^{* *}(.05)$ & $.14^{* *}(.05)$ \\
\hline Problem behavior & $-.25^{* * *}(.07)$ & $-.26^{* * *}(.08)$ & $-.25^{* * *}(.07)$ & $-.31^{* * *}(.05)$ & $-.33 * * *(.06)$ & $-.35^{* * *}(.07)$ \\
\hline Math score & $.14^{* * *}(.03)$ & $.11^{* * *}(.03)$ & $.12^{* * *}(.03)$ & & $.16^{* * *}(.05)$ & $.17^{* * *}(.05)$ \\
\hline Prior SR autonomy support & - & $.41^{* * *}(.08)$ & $.40^{* * *}(.07)$ & & & - \\
\hline Prior SR teacher social support & - & - & & & $(.07)$ & $.29^{* * *}(.07)$ \\
\hline \multicolumn{7}{|l|}{ Classroom/teacher level } \\
\hline Teacher gender & $.01(.03)$ & $.02(.04)$ & $.01(.03)$ & $.03(.01)$ & $.01(.02)$ & $.00(.02)$ \\
\hline e/ethnicity & $.04(.04)$ & .02( & $.01(.03)$ & $-.04(.02)$ & $-.02(.03)$ & $-.02(.03)$ \\
\hline Teaching years & $-.05(.06)$ & $-.03(.07)$ & $-.02(.06)$ & $.10^{* *}(.04)$ & $.08^{* *}(.04)$ & $.09 * *(.05)$ \\
\hline Teacher education & $.03(.07)$ & $.04(.04)$ & $.02(.05)$ & $.02(.08)$ & $.03(.07)$ & $.04(.06)$ \\
\hline Class size & $-.10^{* *}(.03)$ & $-.07^{* *}(.02)$ & $-.06^{*}(.03)$ & $-.12^{* *}(.04)$ & $-.07^{*}(.03)$ & $-.07^{*}(.03)$ \\
\hline Average math score & $.21^{* * *}(.05)$ & $.18^{* * *}(.04)$ & $.19^{* * *}(.04)$ & $.23^{* * *}(.04)$ & $.20^{* * *}(.05)$ & $.22^{* * *}(.05)$ \\
\hline Heterogeneity in math score & $-.05(.08)$ & $-.04(.06)$ & $-.06(.07)$ & $-.09(.06)$ & $-.07(.05)$ & $-.07(.06)$ \\
\hline Ability grouping & $.08(.07)$ & $.05(.09)$ & $.03(.08)$ & $.10(.10)$ & $-.08(.09)$ & $-.07(.08)$ \\
\hline Class size $\times$ Ability grouping & - & $.16^{* * *}(.04)$ & $.15^{* * *}(.04)$ & - & $.08(.04)$ & $.07(.04)$ \\
\hline $\begin{array}{l}\text { Heterogeneity in math } \\
\text { score } \times \text { Ability grouping }\end{array}$ & - & $.20^{* * *}(.04)$ & $.21^{* * *}(.04)$ & - & $.05(.09)$ & $.03(.07)$ \\
\hline TR autonomy support & - & - & & - & - & - \\
\hline TR teacher social suppor & - & . & & - & - & $-.06(.08)$ \\
\hline \multicolumn{7}{|l|}{ School level } \\
\hline School size & $-.03(.08)$ & $-.04(.07$ & $-.02(.08)$ & $-.09(.07)$ & $-.06(.09)$ & $-.04(.09)$ \\
\hline Faculty turnover & $-.04(.05)$ & $-.02(.03)$ & $-.03(.03)$ & $-.10(.08)$ & $-.08(.06)$ & $-.06(.04)$ \\
\hline Student mobility & $.02(.07)$ & $.01(.06)$ & $.02(.07)$ & $.01(.08)$ & $.02(.05)$ & $.01(.05)$ \\
\hline Student-teacher ratio & $-.11^{* *}(.03)$ & $-.09 * *(.03)$ & $-.08 * *(.03)$ & $-.13^{* * *}(.03)$ & $-.11^{* * *}(.02)$ & $-.12^{* * *}(.02$ \\
\hline FARMS & $-.03(.07)$ & $-.02(.05)$ & $-.01(.06)$ & $-.06(.08)$ & $-.04(.09)$ & $-.02(.09)$ \\
\hline AIC & 2003.5 & 1998.2 & 53.4 & 1804.3 & 1798.8 & 1762.3 \\
\hline BIC & 2045.8 & 2039.6 & 2028.4 & 1764.0 & 1760.3 & 1745.8 \\
\hline
\end{tabular}

Note. Student gender, $0=$ female, $1=$ male; student race/ethnicity, $0=$ White, $1=$ non-White; SES = socioeconomic status; SR = student report; teacher gender, $0=$ female, $1=$ male; teacher ethnicity, $0=$ White, $1=$ non-White; teaching years = number of years teacher has taught at this school; teacher education, $0=$ bachelor's degree, $1=$ master's level or higher; class size $=$ number of students in the class; average math score $=$ mean math score in the classroom; TR = teacher report; FARMS = free or reduced-priced meals; $\mathrm{AIC}=$ Akaike information criterion; BIC $=$ Bayesian information criterion.

$* p<.05 ; * * p<.01 ; * * * p<.001$.

The interaction of Class heterogeneity in math achievement $\times$ Within-classroom ability grouping revealed a positive association of within-classroom ability grouping with perceptions of collaboration promotion and autonomy support as heterogeneity in math achievement increases. In other words, students in classes with diverse math ability perceived significantly more collaboration promotion and autonomy support $(\beta s=.25, p<.001$, and .24, $p<.001$ for collaboration and autonomy, respectively) than students in classrooms with less diverse math scores $(\beta s=.05$, ns and .03 , ns for collaboration and autonomy, respectively).

At the school level, a higher student-teacher ratio was negatively related to student perceptions of authentic instruction, collaboration promotion, autonomy support, and teacher social support. Specifically, students in a school with a higher teacher-student ratio perceived lower expectations from teachers, fewer opportunities for collaboration and autonomy, and less teacher social support. Beyond that, none of the other school-level factors reached statistical significance for student perceptions.

Finally, we examined whether teacher report of classroom climate predicted student report of classroom climate. In Model 3 from Tables 2 and 3, scores on teacher perceptions of collaboration promotion and autonomy support were positively associated with student perceptions of collabora- 
TABLE 4

Multilevel Results for School, Classroom, and Individual-Level Effects on Teacher-Reported Authentic Instruction and Collaboration Promotion

\begin{tabular}{|c|c|c|c|c|}
\hline Variables & $\begin{array}{c}\text { Model 1a: } \\
\text { TR Authentic } \\
\text { Instruction } \\
\beta(S E)\end{array}$ & $\begin{array}{c}\text { Model 2a: } \\
\text { TR Authentic } \\
\text { Instruction } \\
\beta(S E)\end{array}$ & $\begin{array}{c}\text { Model 1b: } \\
\text { TR Promoting } \\
\text { Collaboration } \\
\beta(S E)\end{array}$ & $\begin{array}{c}\text { Model 2b: } \\
\text { TR Promoting } \\
\text { Collaboration } \\
\beta(S E)\end{array}$ \\
\hline \multicolumn{5}{|l|}{ Classroom/teacher level } \\
\hline Average student gender & $.03(.03)$ & $.03(.03)$ & $.02(.03)$ & $.02(.03)$ \\
\hline Average student ethnicity & $.00(.02)$ & $.00(.02)$ & $.01(.03)$ & $.01(.03)$ \\
\hline Average student SES & $.02(.03)$ & $.02(.03)$ & $.01(.02)$ & $.01(.02)$ \\
\hline $\begin{array}{l}\text { Average student } \\
\text { problem behavior }\end{array}$ & $.03(.05)$ & $.03(.05)$ & & $-.05(.05)$ \\
\hline Teacher gender & $.12(.13)$ & $.13(.11)$ & $.12(.10)$ & $.14(.13)$ \\
\hline Teacher ethnicity & $.07(.08)$ & $.05(.06)$ & $.04(.06)$ & $.03(.05)$ \\
\hline Teaching years & $.22^{* * *}(.05)$ & $.18^{* * *}(.04)$ & $.16^{* * *}(.03)$ & $.14^{* * *}(.02)$ \\
\hline Teacher education & $.11^{* *}(.03)$ & $.09 * *(.03)$ & $.07 *(.03)$ & $.05^{*}(.02)$ \\
\hline Class size & $-.18^{* * *}(.04)$ & $-.16^{* * *}(.04)$ & $-.19^{* * *}(.03)$ & $-.16^{* * *}(.04)$ \\
\hline Average math score & $.16^{* *}(.05)$ & $.15^{* *}(.05)$ & $.20^{* * *}(.03)$ & $.19^{* * *}(.03)$ \\
\hline Heterogeneity in math score & $-.13^{*}(.05)$ & $-.11^{*}(.04)$ & $.02(.08)$ & $.03(.07)$ \\
\hline Ability grouping & $.05(.03)$ & $.06(.03)$ & $.07(.05)$ & $.05(.06)$ \\
\hline Class size $\times$ Ability grouping & - & $.03(.05)$ & - & $.24^{* * *}(.05)$ \\
\hline $\begin{array}{l}\text { Heterogeneity in math } \\
\text { score } \times \text { Ability grouping }\end{array}$ & - & $.01(.04)$ & - & $.02(.05)$ \\
\hline Prior TR authentic instruction & $.36^{* * *}(.06)$ & $.34^{* * *}(.06)$ & - & - \\
\hline Prior TR collaboration promotion & - & & $.30^{* * *}(.07)$ & $.29 * * *(.06)$ \\
\hline Average SR authentic instruction & $.03(.05)$ & & - & - \\
\hline Average SR collaboration promotion & - & & $.15^{* * *}(.04)$ & $.15^{* * *}(.04)$ \\
\hline Variance in SR authentic instruction & $.05(.07)$ & $.05(.07)$ & - & - \\
\hline Variance in SR collaboration promotion & & & $.02(.05)$ & $.02(.05)$ \\
\hline \multicolumn{5}{|l|}{ School level } \\
\hline School size & $.07(.12)$ & $.05(.10)$ & $-.02(.06)$ & $-.04(.08)$ \\
\hline Faculty turnover & $-.05(.06)$ & $-.04(.07)$ & $.04(.08)$ & $.02(.06)$ \\
\hline Student mobility & $.06(.07)$ & $.04(.05)$ & $-.07^{*}(.03)$ & $-.06^{*}(.03)$ \\
\hline Student-teacher ratio & $-.11 *(.05)$ & $-.10^{*}(.04)$ & $-.13^{* *}(.04)$ & $-.10^{* *}(.04)$ \\
\hline FARMS & $.03(.08)$ & $.05(.07)$ & $.05(.11)$ & $.03(.09)$ \\
\hline AIC & 1257.9 & 1249.3 & 1222.4 & 1214.3 \\
\hline BIC & 1296.6 & 1288.3 & 1258.6 & 1240.3 \\
\hline
\end{tabular}

Note. Student gender, $0=$ female, $1=$ male; student race/ethnicity, $0=$ White, $1=$ non-White; SES = socioeconomic status; teacher gender, $0=$ female, $1=$ male; teacher ethnicity, $0=$ White, $1=$ non-White; teaching years = number of years teacher has taught at this school; teacher education, $0=$ bachelor's degree, $1=$ master's level or higher; class size = number of students in the class; TR = teacher report; SR = student report; average math score = mean math score in the classroom; FARMS = free or reduced-priced meals; $\mathrm{AIC}=$ Akaike information criterion; $\mathrm{BIC}=$ Bayesian information criterion.

$* p<.05 ; * *<.01 ; * * * p<.001$.

tion promotion $(\beta=.26, p<.001)$ and autonomy support $(\beta=.19, p<.05)$. The association between teacher reports and student reports in authentic instruction and teacher social support was not statistically significant, controlling for other level variables (see Tables 2 and 3).

\section{Teacher Models}

The teacher models (see Tables 4 and 5) indicated that teachers with more teaching experience reported greater levels of authentic instruction, collaboration promotion, autonomy support, and social support for students than teachers with less teaching experience. Teachers with a master's degree or higher rated the four aspects of classroom climate more favorably than teachers with a bachelor's degree. There were no significant effects for teacher gender or ethnicity. Teachers in classes with high average math scores reported greater levels of authentic instruction, collaboration promotion, autonomy support, and teacher social support than did teachers in classes with low average math scores. Moreover, teachers reported more authentic instruc- 
TABLE 5

Multilevel Results for School, Classroom/Teacher, and Individual-Level Effects on Teacher-Reported Autonomy Support and Teacher Social Support

\begin{tabular}{|c|c|c|c|c|}
\hline Variables & $\begin{array}{c}\text { Model 1c: } \\
\text { TR Autonomy } \\
\text { Support } \\
\beta(S E)\end{array}$ & $\begin{array}{c}\text { Model 2c: } \\
\text { TR Autonomy } \\
\text { Support } \\
\beta(S E)\end{array}$ & $\begin{array}{c}\text { Model } 1 d: \\
\text { TR Teacher } \\
\text { Social Support } \\
\beta(S E)\end{array}$ & $\begin{array}{c}\text { Model 2d: } \\
\text { TR Teacher } \\
\text { Social Support } \\
\beta(S E)\end{array}$ \\
\hline \multicolumn{5}{|l|}{ Classroom/teacher level } \\
\hline Average student gender & $-.01(.04)$ & $-.01(.04)$ & $.00(.02)$ & $.00(.02)$ \\
\hline Average student ethnicity & $-.00(.05)$ & $-.00(.05)$ & $.00(.04)$ & $.00(.04)$ \\
\hline Average student SES & $.01(.04)$ & $.01(.04)$ & $.01(.03)$ & $.01(.03)$ \\
\hline Average student problem behavior & $-.06(.05)$ & $-.06(.05)$ & $-.04(.05)$ & $-.04(.03)$ \\
\hline Teacher gender & $.15(.14)$ & $.13(.12)$ & $.14(.08)$ & $.12(.09)$ \\
\hline Teacher ethnicity & $.04(.06)$ & $.02(.04)$ & $.04(.08)$ & $.02(.06)$ \\
\hline Teaching years & $.14^{* * *}(.03)$ & $.12^{* * *}(.03)$ & $.15^{* * *}(.03)$ & $.12^{* * *}(.03)$ \\
\hline Teacher education & $.13^{* * *}(.03)$ & $.13^{* * *}(.03)$ & $.07^{*}(.03)$ & $.05^{*}(.02)$ \\
\hline Class size & $-.18^{* * *}(.04)$ & $-.15^{* * *}(.04)$ & $-.16^{* * *}(.03)$ & $-.14^{* *}(.04)$ \\
\hline Average math score & $.23^{* * *}(.04)$ & $.21 * * *(.05)$ & $.20^{* * *}(.05)$ & $.17^{* * *}(.04)$ \\
\hline Heterogeneity in math score & $.08(.11)$ & $.06(.10)$ & $.06(.05)$ & $.05(.07)$ \\
\hline Ability grouping & $.07(.04)$ & $.06(.04)$ & $-.05(.03)$ & $-.04(.08)$ \\
\hline Class size $\times$ Ability grouping & - & $.19 * * *(.04)$ & - & $.12(.06)$ \\
\hline $\begin{array}{l}\text { Heterogeneity in math } \\
\text { score } \times \text { Ability grouping }\end{array}$ & - & $.01(.06)$ & - & $.02(.03)$ \\
\hline Prior TR autonomy support & $.28^{* * *}(.05)$ & $.27^{* * *}(.05)$ & - & - \\
\hline Prior TR teacher social support & - & - & $.38^{* * *}(.08)$ & $.37^{* * *}(.07)$ \\
\hline Average SR autonomy support & $.14^{*}(.05)$ & $13^{*}($. & - & - \\
\hline Average SR teacher social support & - & & $.04(.06)$ & $.04(.06)$ \\
\hline Variance in SR autonomy support & $.03(.06)$ & $.03(.06)$ & - & - \\
\hline Variance in SR teacher social support & & - & $.01(.07)$ & $.01(.07)$ \\
\hline \multicolumn{5}{|l|}{ School level } \\
\hline School size & $-.03(.12)$ & $-.01(.09)$ & $-.06(.10)$ & $-.03(.12)$ \\
\hline Faculty turnover & $.05(.06)$ & $.03(.04)$ & $.02(.08)$ & $.01(.07)$ \\
\hline Student mobility & $-.08^{*}(.03)$ & $-.07^{*}(.03)$ & $.05(.07)$ & $.02(.05)$ \\
\hline Student-teacher ratio & $-.12^{* *}(.04)$ & $-.09^{* *}(.04)$ & $-.17^{* * *}(.03)$ & $-.14^{* * *}(.03)$ \\
\hline FARMS & $.04(.09)$ & $.02(.10)$ & $-.04(.11)$ & $-.02(.10)$ \\
\hline AIC & 1309.4 & 1298.3 & 1211.0 & 1202.0 \\
\hline BIC & 1333.5 & 1323.1 & 1253.3 & 1240.3 \\
\hline
\end{tabular}

Note. Student gender, 0 = female, $1=$ male; student race/ethnicity, $0=$ White, 1 = non-White; SES = socioeconomic status; teacher gender, 0 = female, 1 = male; teacher ethnicity, $0=$ White, $1=$ non-White; teaching years = number of years teacher has taught at this school; teacher education, $0=$ bachelor's degree, $1=$ master's level or higher; class size $=$ number of students in the class; TR = teacher report; $\mathrm{SR}=$ student report; average math score = mean math score in the classroom; FARMS = free or reduced-priced meals; $\mathrm{AIC}=$ Akaike information criterion; BIC $=$ Bayesian information criterion.

$* p<.05 ; * * p<.01 ; * * * p<.001$.

tion in classes of smaller size, while less authentic instruction was reported in classes where there was a greater heterogeneity in student math abilities.

The within-classroom-level interaction (Class size $\times$ Within-classroom ability group grouping) represents the differences in perceived classroom climate as class size increases in classrooms using within-classroom ability grouping compared with classrooms with no within-classroom ability grouping. The positive association of within-classroom ability grouping with classroom climate increases with the class size: for each of the two aspects of classroom climate, the positive associations of within-classroom ability grouping with promoting collaboration and autonomy support were insignificant in small classes ( $\beta s=.05$ and .06 for collaboration and autonomy, respectively) but significant in larger classes $(\beta s=.29$ and .27 for collaboration and autonomy support, respectively).

At the school level for teachers, greater student mobility was associated with lower levels of perceived collaboration promotion and autonomy support. High student-teacher ratio was negatively associated with teacher reports of authentic instruction, collaboration promotion, autonomy support, and teacher social support. School size, faculty turnover, and percentage of students receiving free or reduced-priced meals were not associated with 
any aspects of classroom climate examined in the study.

\section{DISCUSSION}

In this study, we employed a multilevel approach to identify what individual-, classroom-, and school-level factors predict student and teacher perceptions of math classroom climate. We focused on four aspects of classroom climate: authentic instruction, collaboration promotion, autonomy support, and teacher social support. Our findings suggest that factors at all three levels (individual, classroom, and school level) influence both students' and teachers' perceptions of their math classrooms differently. As hypothesized, classroom-level characteristics exerted greater influence upon the classroom perceptions of both students and teachers than school-level characteristics. Students' perceptions of math classroom climate were more influenced by student characteristics than by classroom or teacher or school characteristics and varied more within rather than between classrooms. Furthermore, we only found small correlations between student and teacher reports on promotion of collaboration and provision of autonomy support, but no relationship for authentic instruction and teacher social support. Finally, the effect of within-class ability grouping on perceived classroom climate varied by class size and heterogeneity among classmates' math ability.

\section{Individual-Level Predictors}

Consistent with prior studies (Battistich et al., 1995; Griffith, 2000; Kuperminc et al., 2001; Lou et al., 1996), we found that individual-level factors such as student gender, SES, academic abilities, and problem behavior were associated with students' perceptions of their math classroom context: students who were females, had parents with higher education and annual income and had higher prior mathematics test scores, and fewer problem behaviors perceived more collaboration, autonomy support, and teacher social support than their peers. Two hypotheses can be put forward to interpret these within-class variations in students' perceptions of classroom characteristics: (1) students are treated differently due to differences in individual characteristics by their teachers and peers within their classroom or (2) students' individual and family characteristics lead them to perceive similar treatment differently. We believe both of these processes are operative. The findings suggest that more advantaged students (e.g., students with high SES and academic ability) are likely to be exposed to more "opportunities to learn" or increased levels of classroom instruction (Alexander, Entwisle, \& Olson, 2001; Guarino, Hamilton, Lockwood, Rathbun, \& Germino-Hausken, 2006). They are also consistent with studies of differential within-classroom treatment for girls and boys, suggesting that boys are in fact treated more favorably by their teachers even when their prior achievement levels and engagement in problematic behaviors are controlled for (Cooper \& Good, 1983; Darling-Hammond, 1995). However, it is also likely that students' perceptions are affected by personal characteristics due to individual differences in attributional processes, such as non-conscious cognitive and emotional frames of references (Wigfield et al., 2006). Moreover, students' family characteristics and experiences with parents may also contribute to how they perceive the classroom climate. For example, students from higher SES backgrounds may receive more autonomy support from their parents and thus be more prone to perceive the same autonomy support from their teachers. Similarly, students whose parents are more involved in school education are more likely to internalize the educational values of parents and thus interpret experiences in school with a positive bias (Hill \& Tyson, 2009).

Our findings suggest that school interventions aimed at enhancing students' perceptions of classroom climate may be more effective if they target students who perceive classroom climate less favorably (e.g., male, lower SES, and low-performing students). Given that our findings resonate so well with previous research on differential withinclassroom teacher treatment, it is quite likely that at least some of the within-classroom variation in students' perceptions - disproportionately negative among male, minority, and low SES students (Battistich et al., 1995; Griffith, 2000; Jussim \& Harber, 2005; Kuperminc et al., 2001)—reflects differential teacher treatment (e.g., Guarino et al., 2006). Therefore, interventions need to focus on teacher-student interactions with an eye to differential teacher treatment and getting teachers to treat all of their students more equitably while also fostering change in students' perceptual and attributional processes. Indeed, suggestions for interventions of this nature are now quite prevalent within the social psychology of motivation (e.g., Hulleman \& Harackiewicz, 2010).

It is noteworthy that females perceived their math teachers as providing less authentic instruc- 
tion than their male classmates, even after controlling for prior math scores and engagement in problematic behaviors despite the fact girls rated the other characteristics of their math classroom climate more positively than did boys. These girls were less likely than their male peers to think that the math curriculum is meaningful or relevant to their personal goals and interests. Many scholars interested in the gender differences in participation in math-intensive STEM careers have speculated that this might be one reason girls are less likely to continue taking advanced math courses (Ceci \& Williams, 2010; Wang, Eccles, \& Kenny, 2013) because authentic instruction has been shown to be a strong predictor of career interests and choices in math-intensive fields. Gender differences in levels of perceived authentic instruction may reflect a tendency on behalf of the teacher to associate math with characteristically male-dominated activities, careers, and domains, such as engineering and the physical sciences. If this were the case, it would explain why boys were more likely than girls to perceive their math teacher as teaching for meaning and relevance. This assumption also goes some way in explaining career aspiration differences: if boys connect what is going on in math class to the outside world, their math utility value will increase, in turn positively influencing math-related career aspirations. Indeed, girls in middle and high school years in general report lower estimates of math utility values than their male peers, despite equivalent math performance and this difference mediates gender differences in advanced math course enrollments in the twelfth grade (ElseQuest, Hyde, \& Linn, 2010). It is plausible that gender differences in math utility values in part originate from gender differences in perception of level of authentic instruction taking place in the classroom (Wang, 2012; Wigfield et al., 2006).

\section{Classroom or Teacher-Level Predictors}

The patterns of results for within-classroom grouping were different. The use of within-class ability grouping has often been cited as a possible approach for increasing math performance in classes with different skill levels. When we found effects of within-classroom ability grouping, the results suggested positive consequences for both students' and teachers' perceptions of classroom climate. However, this was only true when the class size was large and the heterogeneity of ability levels was large. Under these conditions, the students in ability-grouped math classes rated their classrooms as providing more support for their autonomy, more opportunities for collaborative learning, and more teacher support, all of which should increase the students' motivation to learn math. Similarly, when class size was large, the teachers in ability-grouped classrooms reported greater use of collaborative learning opportunities and more support for autonomy. Thus, as class size and heterogeneity of ability levels increase, the use of within-classroom ability grouping may be an effective technique for improving student and teacher perceptions of classroom climate that the teachers provide high-quality learning opportunities for all students in the class regardless of their ability-grouping status.

\section{School-Level Predictors}

In general, school-level factors affected teachers' classroom perceptions more than students' classroom perceptions. High student-teacher ratio was negatively related to both students' and teachers' perceptions of authentic instruction, collaboration promotion, autonomy support, and teacher social support. This finding is consistent with the theory of stage-environment fit (Eccles et al., 1993). The need for close relationships between teachers and students may be particularly important at this age. However, the decrease in the opportunity for such relationships is one of the major changes associated with the transition to middle school due to the increasing size of the overall student body and an increase in the number of students being taught by each teacher. A larger student-to-teacher ratio likely increases teachers' work load and makes class more difficult to manage. Similarly, having a large number of students with fewer interactions with each teacher is inconsistent with the student's need for deep relationships with adult outside their family, and such students are more likely to perceive the classroom environment less favorably (Eccles \& Roeser, 2011).

Recent school reform initiatives have focused on creating small schools and learning communities (e.g., the Federal Smaller Learning Communities Initiative; the Coalition Campus Schools Project). Our results suggest that reducing class size could function as an effective strategy for increasing positive perceptions of classroom climate. We found no evidence of a positive association between school size and our indicators of math classroom climate. Rather, we found that smaller class size and lower student-teacher ratios have positive associations with both students' and teachers' perceptions of 
math classroom climate. This finding is not surprising given that it is the daily interactions between students and teachers in the classroom that create classroom climate. Smaller class size and lower student-teacher ratios foster greater interaction between students and their teachers, allowing positive and meaningful relationships to develop, and providing teachers with greater opportunity to promote collaboration and support autonomy in students. These findings indicate that it is not the overall size of the organization that matters, but rather the size of the units in which the teachers and students actually interact on a daily basis (Meier, 2002). Further support for this conclusion is provided by the fact that greater student mobility at the school level predicted reduced frequency of teacher promotion of collaborative learning and autonomy support. Both teaching strategies rely on trust between students and teachers. If the turnover rate for students is high, teachers will have less opportunity to develop trusting relationships with their students, which, in turn, will reduce the likelihood of use of collaborative learning tasks and provision of support for autonomous learning.

\section{The Convergence and Divergence Between Student and Teacher Perceptions}

By and large, we did not find a strong association between students' and teachers' perceptions of classroom climate. Only small correlations were found between student and teacher reports on promotion of collaboration and provision of autonomy support, but no relationship for authentic instruction and teacher social support. We did not have qualitative interview data to understand why responses may converge or differ (Desimone \& LeFloch, 2004), but results from previous research suggest that it might be due to the degree of subjectivity captured by the classroom climate measure (Desimone, Smith, \& Frisvold, 2010; Mitchell et al., 2010). For example, reporting levels of provision of autonomy and collaboration may be less subjective than reporting perceptions of authentic instruction and teacher social support. If this is the case, it is reasonable to expect convergence on perceived autonomy support and collaboration but divergence on perceived teacher social support.

Many psychological models of school influence on student socio-emotional development take student perception of teacher behavior and classroom climate to be the most important predictors of these constructs (e.g., Esposito, 1999; Kasen, Johnson, \& Cohen, 1990). However, the relatively weak relationship between student and teacher reports of classroom climate in our study suggests that different stakeholders may have different views about their math class climate. Students' perceptions of classroom characteristics typically vary more within classrooms than between classrooms and so it was with this study. Although some of this variation undoubtedly reflects differential teacherstudent interactions within the classroom, some of the variation also likely reflects differences in baseline student and family characteristics: characteristics the students had when they first entered the class. Thus, we must be cautious in using student perceptions of classroom climate as the only indicators of shared aspects of the classroom characteristics. Use of such measures is likely to underestimate the impact of classroom reform efforts aimed at changing classroom climate or shared classroom characteristics for two reasons: (1) these measures reflect multiple sources of bias, and (2) to the extent that the influence of classroom characteristics on student outcomes depends on students' perceptions of their classrooms, the same interventions and the same teacher practices are likely to have differential impact on different students within the same classroom.

Similarly, teachers' perceptions are likely to have reporter biases and thus are prone to produce underestimations of the impact of reform efforts targeted at changing classroom climate. Teachers may be more sensitive to and accommodating toward the expectations of the researchers than students. For example, teachers may be more prone to believe that it is not socially appropriate to attribute variations in classroom climate to student characteristics such as gender or social class. That is, despite their actual beliefs and even their actions, teacher participants may be prone to report to researchers the culturally valued dictum. Therefore, both teacher and student biases are likely to affect perceptions of classroom climate and the likelihood that the teacher will implement the reform efforts differentially among students. Averaging student and teacher classroom perceptions without taking into account the individual characteristics influencing their perceptions can underestimate the impact of the intervention on some individuals. Though logistic and resource constraints often do not allow us to administer surveys to multiple respondents, we need to be aware of the implications of our choice of respondent as well as the specific aspects of classroom climate being assessed when interpreting the results of our analysis. 
Our findings suggest that interventions to promote effective classrooms may target not only teacher behavior (e.g., instructional strategies and classroom management), but also students' classroom perceptions. The more subjective aspects of classroom climate such as perceived teacher support or perceived authentic instruction would be particularly relevant to interventions. Recent studies in social psychology have shown the power of changing students' perceptions of their own motivation and ability (Dweck, 2006), as well as their perceptions of the learning contexts in which they find themselves (Lizzio, Wilson, \& Simmons, 2002). Similarly, work in mindfulness and compassion training has shown that changing perception of others' motivation can facilitate increased positive interaction between individuals (Trigwell \& Prosser, 1991). Much of this research has involved college students, but perhaps future consideration should be given to such interventions in Grades K-12.

\section{Limitations, Future Research, and Conclusions}

Several limitations and some caveats to this study must be noted. First, this study's sample was comprised primarily of European American adolescents in one region of the country and was not representative of the wider general U.S. population. Therefore, any generalizations must be approached with caution. Replication of these findings using more ethnically diverse samples is needed. Similarly, we focused only on math classrooms, and the results can be generalized to math only. Future studies in other school subjects will test the generalizability of our findings across subject domains. Third, we examined only four aspects of classroom climate. Future studies would benefit from taking peer dynamics and interaction into account. Encompassing these variables would allow us to investigate the full complexity of peer social experience on students' beliefs and perceptions of classroom climate. In addition, future studies should investigate whether the influences of individual and contextual characteristics on our classroom climate measures reflect perceptual biases or actual differences in experience. The use of observational assessments will be an important step as a validation study for student and teacher report measures.

Despite its limitations, this study extends previous research in a number of ways. We have highlighted the need to take both an ecological-level perspective and a developmental perspective on perceptions of classroom climate. The study not only advances our understanding of how the multiple levels of school organization interact to shape perceptions of the day-to-day experiences of students and teachers, but also what individual and contextual characteristics lead to supportive math classroom climate. The findings also provide important insights into measurement and analysis of setting level constructs by examining multi level predictors of classroom climate from multiple perspectives. With increasing focus on the design, implementation, and evaluation of intervention programmes aimed at creating an effective school, classrooms are often a setting in which these programmes are implemented (Greenberg, Domitrovich, \& Bumbarger, 2001). Our study provides an illustration of how it is the complex configurations of multiple factors in school systems, not single factors acting in isolation, that account for the perception of "positive classroom climate." These findings underscore the importance of assessing both student and teacher perceptions to better understand classroom climate, especially when monitoring the outcomes of classroom improvement initiatives.

\section{REFERENCES}

Akaike, H. (1974). A new look at the statistical model identification. IEEE Transactions on Automatic Control, 19, 716-723.

Akiba, M., LeTendre, G. K., \& Scribner, J. P. (2007). Teacher quality, opportunity gap, and national achievement in 46 countries. Educational Researcher, 36, 369-387.

Alexander, K. L., Entwisle, D. R., \& Olson, L. S. (2001). School, achievement, and inequality: A seasonal perspective. Educational Evaluation and Policy Analysis, 23, 171-191.

Archibald, S. (2006). Narrowing in on educational resources that do affect student achievement. Peabody Journal of Education, 81, 23-42.

Baker, J. A. (1999). Teacher-student interaction in urban at-risk classrooms: Differential behavior, relationship quality, and student satisfaction with school. Elementary School Journal, 100, 57-70.

Baker, J. A., Derrer, R. D., Davis, S. M., Dinklage-Travis, H. E., Linder, D. S., \& Nicholson, M. D. (2001). The flip side of the coin: Understanding the school's contribution to dropout and completion. School Psychology Quarterly, 16, 406-426.

Barth, J. M., Dunlap, S. T., Dane, H., Lochman, J. E., \& Wells, K. C. (2004). Classroom environment influences on aggression, peer relations, and academic focus. Journal of School Psychology, 42, 115-133.

Battistich, V., Solomon, D., Kim, D., Watson, M., \& Schaps, E. (1995). Schools as communities, poverty levels of student populations, and students' attitudes, 
motives, and performance: A multilevel analysis. American Educational Research Journal, 32, 627-658.

Bevans, K. B., Bradshaw, C. P., Miech, R., \& Leaf, P. J. (2007). School-level predictors of school organizational health: A multilevel analysis. Journal of School Health, 77, 294-303.

Birnbaum, A. S., Lytle, L. A., Hannan, P. J., Murray, D. M., Perry, C. L., \& Forester, J. L. (2003). School functioning and violent behavior among young adolescents: A contextual analysis. Health Education Research, 18, 389-403. doi:10.1111/j.1746-1561.2003.tb06568.x

Bronfenbrenner, U. (1979). The ecology of human development: Experiments by nature and design. Cambridge, MA: Harvard University Press.

Ceci, S. J., \& Williams, W. M. (2010). Sex differences in math-intensive fields. Current Directions in Psychological Science, 19, 275-279.

Cleary, T. J., \& Chen, P. P. (2009). Self-regulation, motivation, and math achievement in middle school: Variations across grade level and math context. Journal of School Psychology, 47, 291-314.

Connell, J. P., \& Wellborn, J. G. (1991). Competence, autonomy, and relatedness: A motivational analysis of self-system processes. In M. R. Gunnar \& L. A. Sroufe (Eds.), Self processes in development: Minnesota Symposium on Child Psychology (Vol. 23, pp. 43-77). Chicago, IL: University of Chicago Press.

Cooper, H. M., \& Good, T. L. (1983). Teacher and student perceptions of interactions frequencies. In H. M. Cooper \& T. L. Good (Eds.), Pygmalion grows up: Studies in the expectation communication process (pp. 47-55). New York, NY: Longman.

Darling-Hammond, L. (1995). Inequality and access to knowledge. In J. A. Banks, \& C. A. M. Banks (Eds.), Handbook of research on multicultural education (pp. 465483). New York, NY: Macmillan.

Darling-Hammond, L., Ancess, J., \& Ort, S. W. (2002). Reinventing high school: Outcomes of the Coalition Campus School Project. American Educational Research Journal, 39, 639-673.

Deci, E., \& Ryan, R. M. (2000). What is the self in selfdirected learning? Findings from recent motivational research. In G. Staka (Ed.), Conceptions of self-directed learning: Theoretical and conceptual considerations. Munster, Germany: Waxmann.

Desimone, L., \& LeFloch, K. (2004). Probing the "trickle down" effect of standards and assessments: Are we asking the right questions? Educational Evaluation and Policy Analysis, 26, 1-22.

Desimone, L. M., Smith, T. M., \& Frisvold, D. E. (2010). Survey measures of classroom instruction: Comparing student and teacher reports. Educational Policy, 24, 267-312.

Deutsch, F. M. (2003). How small classes benefit high school students. National Association of Secondary School Principals Bulletin, 87, 35-44.

Dweck, C. S. (2006). Is math a gift? Beliefs that put females at risk. In S. J. Ceci, \& W. M. Williams (Eds.), Why aren't more women in science? Top researchers debate the evidence (pp. 47-55). Washington, DC: American Psychological Association.

Eccles, J. S., Lord, S., \& Midgley, C. (1991). What are we doing to early adolescents? The impacts of educational contexts on early adolescents American Educational Journal, 99, 521-542.

Eccles, J. S., Lord, S. E., Roeser, R. W., Barber, B. L., \& Jozefowicz, D. M. (1997). The association of school transitions in early adolescence with developmental trajectories through high school. In J. Schulenberg, J. I. Maggs, \& K. Hurrelmann (Eds.), Health risks and developmental transitions during adolescence (pp. 283-321). New York, NY: Cambridge University Press.

Eccles, J. S., Midgley, C., Wigfield, A., Buchanan, C. M., Reuman, D., Flanagan, C. \& Mac Iver, D. (1993). Development during adolescence: The impact of stage/environment fit. American Psychologist, 48, 90101.

Eccles, J. S., \& Roeser, R. W. (2011). Schools as developmental context during adolescence. Journal of Research on Adolescence, 21, 225-241.

Elliott, D. S., Huizinga, D., \& Menard, S. (1989). Multiple problem youth: Delinquency, substance use, and mental health problems. New York, NY: Springer-Verlag.

Else-Quest, N. M., Hyde, J. S., \& Linn, M. C. (2010). Cross-national patterns of gender differences in mathematics: A meta-analysis. Psychological Bulletin, 136, 103-127.

Epstein, M., Atkins, M., Cullinan, D., Kutash, K., \& Weaver, R. (2008). Reducing behavior problems in the elementary school classroom: A practice guide (NCEE 2008-012). Washington, DC: National Center for Education Evaluation and Regional Assistance, Institute of Education Sciences, US Department of Education. Available at http://ies.ed. gov/ncee/wwc/publications/practiceguides

Esposito, C. (1999). Learning in urban blight: School climate and its effect on the school performance of urban, minority low-income children. School Psychology Review, 28, 365-377.

Feldlaufer, H., Midgley, C., \& Eccles, J. S. (1988). Student, teacher, and observer perceptions of the classroom environment before and after the transition to junior high school. Journal of Early Adolescence, 8, 133-156.

Flores, M. M., \& Kaylor, M. (2007). The effects of a direct instruction program on the fraction performance of middle school students at risk for failure in mathematics. Journal of Instructional Psychology, 34, 84-95.

Foundation for Success. (2008). The final report of the National Mathematics Advisory Panel. Washington, DC: U.S.: Department of Education.

Fuligni, A. J., Eccles, J. E., \& Barber, B. L. (1995). The long term effects of seventh-grade ability grouping in mathematics. Journal of Early Adolescence, 15, 58-89.

Gamoran, A., \& Mare, R. D. (1989). Secondary school tracking and educational inequity: Compensation, reinforcement, or neutrality? American Journal of Sociology, 94, 1146-1183. 
Gentry, M., \& Owen, S. V. (2004). Secondary student perceptions of classroom quality: Instrumentation and differences between advanced/honors and nonhonors classes. Journal of Advanced Academics, 16, 20-29. doi:10. 4219/jsge-2004-464

Green, S. K. (2002). Using an expectancy-value approach to examine teachers' motivational strategies. Teaching and Teacher Education, 18, 989-1005.

Greenberg, M. T., Domitrovich, C. E., \& Bumbarger, B. (2001). The prevention of mental disorders in children: Current state of the field. Prevention and Treatment, 4, 23-35.

Griffith, J. (1995). An empirical examination of a model of school climate in elementary schools. Basic and Applied Social Psychology, 17, 97-117.

Griffith, J. (2000). School climate as group evaluation and group consensus: Student and parent perceptions of the elementary school environment. Elementary School Journal, 101, 35-61.

Guarino, C. M., Hamilton, L. S., Lockwood, J. R., Rathbun, A., \& Germino-Hausken, E. (2006). Teacher qualifications, instructional practices, and reading and mathematic gains of kindergartners (No. NCES 2006-031). Washington, DC: U.S. Department of Education, National Center for Education Statistics.

Haughey, M., Snart, F., \& Costa, J. D. (2001). Math achievement in small classes in high-poverty environments. Canadian Journal of Education, 26, 301-320.

Hill, N. E., \& Tyson, D. F. (2009). Parental involvement in middle school: A meta-analytic assessment of strategies that promote achievement. Developmental Psychology, 45, 740-763. doi:10.1037/a0015362

Hoy, W. K., \& Woolfolk, A. E. (1993). Teachers' sense of efficacy and the organizational health of schools. Elementary School Journal, 93, 355-372.

Hulleman, C. S., \& Harackiewicz, J. M. (2010). Enhancing interest and performance with a utility value intervention. Journal of Educational Psychology, 102, 880-895. doi:10.1037/a0019506

Jussim, L., \& Harber, K. D. (2005). Teacher expectations and self-fulfilling prophecies: Knowns and unknowns, resolved and unresolved controversies. Personality and Social Psychology Review, 9, 131-155.

Kasen, S., Johnson, J., \& Cohen, P. (1990). The impact of school emotional climate on student psychopathology. Journal of Abnormal Child Psychology, 18, 165-177.

Koedel, Cory. (2009). An empirical analysis of teacher spillover effects in secondary school. Economics of Education Review, 28, 682-692.

Koth, C., Bradshaw, C. P., \& Leaf, P. J. (2008). A multilevel study of predictors of student perceptions of school climate: The effect of classroom-level factors. Journal of Educational Psychology, 100, 96-104.

Kuperminc, G. P., Leadbeater, B. J., \& Blatt, S. J. (2001). School social climate and individual differences in vulnerability to psychopathology among middle school students. Journal of School Psychology, 39, 141-159.

Lee, V. E., Smith, J. B., \& Croninger, R. G. (1997). How high school organization influences the equitable dis- tribution of learning in mathematics. Sociology of Education, 70, 128-150.

Leithwood, K., \& Jantzi, D. (2009). A review of empirical evidence about school size effects: A policy perspective. Review of Educational Research, 79, 464-490.

Lizzio, A., Wilson, K., \& Simons, R. (2002). University students' perceptions of the learning environment and academic outcomes: Implications for theory and practice. Studies in Higher Education, 21, 27-52. doi:10.1080/ 03075070120099359

Lou, Y., Abrami, P. C., Spence, J. C., Poulsen, C., Chambers, B., \& d'Apollonia, S. (1996). Within-class grouping: A meta-analysis. Review of Educational Research, 66, 423-458.

Mac Iver, D. (1988). Classroom environments and the stratification of students' ability perceptions. Journal of Educational Psychology, 80, 495-505.

Marks, H. M. (2000). Student engagement in instructional activity: Patterns in elementary, middle and high school years. American Educational Research Journal, 37, 153-184.

McNeely, C. A., Nonnemaker, J. M., \& Blum, R. W. (2002). Promoting school connectedness: Evidence from the National Longitudinal Study of Adolescent Health. Journal of School Health, 72, 138-146.

Meier, D. (2002). In schools we trust: Creating communities of learning in an era of testing and standardization. Boston, MA: Beacon Press.

Meyer, D. K., \& Turner, J. C. (2002). Discovering emotion in classroom motivation research. Educational Psychologist, 37, 107-114.

Midgley, C., Feldlaufer, H., \& Eccles, J. S. (1989). Change in teacher efficacy and student self and task-related beliefs in mathematics during the transition to junior high school. Journal of Educational Psychology, 81, 247-258.

Midgley, C., Kaplan, A., Middleton, M., Maehr, M., Urdan, T., Hicks Anderman, L., Anderman, E., \& Roeser, R. (1998). The development and validation of scales assessing students' achievement goal orientations. Contemporary Educational Psychology, 23, 113-131. doi:10. 1006/ceps.1998.0965

Mitchell, M. M., Bradshaw, C. P., \& Leaf, P. L. (2010). Student and teacher perceptions of school climate: A multilevel exploration of patterns of discrepancy. Journal of School Health, 80, 271-279.

Mulkey, L. M., Catsambia, S., Steelman, L. C., \& Crain, R. L. (2005). The long-term effect of ability grouping in mathematics: A national investigation. Social Psychology of Education, 8, 137-177.

Newman, F. M., \& Wehlage, G. G. (1993). Five standards of authentic instruction. Educational Leadership, 50, 8-12.

Patrick, H., Kaplan, A., \& Ryan, A. M. (2011). Positive classroom motivational environments: Convergence between mastery goal structure and classroom social structure. Journal of Educational Psychology, 103, 367382. 
Pianta, R. C., \& Hamre, B. K. (2009). Conceptualization, measurement, and improvement of classroom processes: Standardized observation can leverage capacity. Educational Researcher, 38, 109-119.

Powers, J. M. (2003). An analysis of performance-based accountability: Factors shaping school performance in two urban school districts. Educational Policy, 17, 558585.

Raudenbush, S. W., \& Bryk, A. S. (2002). Hierarchical linear models: Applications and data analysis methods (vol. 2). Thousand Oaks, CA: Sage.

Raudenbush, S. W., Bryk, A., \& Congdon, R. (2005). HLM statistical software: Version 6. Lincolnwood, IL: Scientific Software International.

Reeve, J., Jang, H., Carrell, D., Jeon, S., \& Barch, J. (2004). Enhancing students' engagement by increasing teachers' autonomy support. Motivation and Emotion, 28, 147-169.

Rockoff, J. E. (2004). The impact of individual teachers on student achievement: Evidence from panel data. American Economic Review, 94, 247-252.

Roeser, R. W., \& Eccles, J. S. (1998). Adolescents' perceptions of middle school: Relation to longitudinal changes in academic and psychological adjustment. Journal of Research on Adolescence, 8, 123-158. doi:10. 1207/s15327795jra0801_6

Rosenholtz, S. J. (1989). Workplace conditions that affect teacher quality and commitment: Implications for teacher induction programs. The Elementary School Journal, 89, 420-439.

Rutter, M., \& Maughan, B. (2002). School effectiveness findings. Journal of School Psychology, 40, 451-475.

Ryan, R. M., \& Grolnick, W. S. (1986). Origins and pawns in the classroom: Self-report and projective assessments of individual differences in children's perceptions. Journal of Personality and Social Psychology, 50, 550-558.

Skinner, E. A., \& Belmont, M. J. (1993). Motivation in the classroom: Reciprocal effects of teacher behavior and student engagement across the school year. Journal of Educational Psychology, 85, 571-581. doi:10.1037/0022bbb0663.85.4.571

Singer, J. D., \& Willett, J. B. (2003). Applied longitudinal data analysis: Modeling change and event occurrence. Oxford: Oxford University Press.

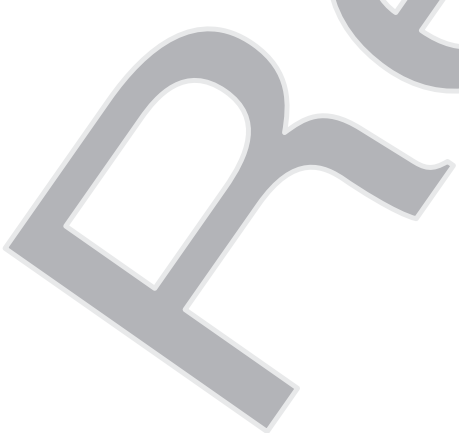

Tiedemann, J. (2002). Teachers' gender stereotypes as determinants of teacher perceptions in elementary school mathematics. Educational Studies in Mathematics, 50, 49-62. doi:10.1023/A:1020518104346

Trigwell, K., \& Prosser, M. (1991). Improving the quality of student learning: The influence of learning context and student approaches to learning on learning outcomes. Higher Education, 22, 251-266. doi:10.1007/ BF00132290

Wang, M. T. (2009). School support for adolescents' behavioral and psychological adjustment: Testing mediating effect of social competence. School Psychology Quarterly, 24, 240-251.

Wang, M. T. (2012). Educational and career interests in math: A longitudinal examination of the links between perceived classroom environment, motivational beliefs, and interests. Developmental Psychology, 48, 1643-1657.

Wang, M. T., \& Degol, J. (2013). Motivational pathways to STEM career choices: Using expectancy-value perspective to understand individual and gender differences in STEM fields. Developmental Review, 33, $304-340$.

Wang, M. T., \& Eccles, J. S. (2012). Social support matters: Longitudinal effects of social support on three dimensions of school engagement from middle to high school. Child Development, 83, 877-895.

Wang, M. T., Eccles, J. S., \& Kenny, S. (2013). Not lack of ability but more choice: Individual and gender differences in STEM career choice. Psychological Science, 24, 770-775.

Wang, M. T., \& Holcombe, R. (2010). Adolescents' perceptions of classroom environment, school engagement, and academic achievement. American Educational Research Journal, 47, 633-662.

Welsh, W. N. (2000). The effects of school climate on school disorder. Annals of the American Academy of Political and Social Science, 567, 88-107.

Wigfield, A., Eccles, J. S., Davis-Kean, P., Roeser, R., \& Scheifele, U. (2006). Motivation to succeed. In W. Damon (Ed.), N. Eisenberg (Series Ed.), Handbook of child psychology (6th ed.): Vol. 3. Social, emotional, and personality development (pp. 933-1002). New York, NY: Wiley. 